\title{
Developing Anglo American's integrated closure planning system requires people, process and technology working together
}

\author{
CD Grant Anglo American, Australia \\ HWB Lacy MWH Australia Pty Ltd, Australia
}

\begin{abstract}
Integrating closure planning with other mine-planning processes is not a new idea. While most would agree on the benefits of such an approach, examples where the potential is realised remain the exception. Anglo American commenced the development of an Integrated Closure Planning System (ICPS) with the aim to provide a consistent approach over the lifecycle of projects for the reporting and management of long-term liabilities, to achieve their goal of ensuring that they leave a positive and sustainable legacy for their host communities after their operations have closed. We propose that to achieve this objective requires focus on people, process and technology. The elements of the ICPS are: planning (e.g. life-of-mine (LOM), closure, short/medium term mine, rehabilitation), financials (e.g. premature and LOM closure liability, operational expenditure, guarantees), systems (e.g. closure toolboxes, Geographic Information Systems, Environmental Management Systems) and requirements (e.g. internal/external standards, policy, regulation). A multi-disciplinary team comprising mine closure, mining engineering/planning, technology and business process experts from Anglo and MWH was formed to develop the ICPS. The process involved identifying the current state of processes and systems, the target state of a fully integrated process, developing a maturity scorecard and identifying potential technology solutions that may assist in realising value at the operational level. In defining the current condition across the operations it became evident that roles and responsibilities were not clear across the organisation, both the LOM and immediate mine planning processes had no clear platform or process to facilitate closure planning interactions, and that over 40 software solutions were being used across Anglo's business units. This finding reinforced the importance and emphasised the critical nature of the 'people, process and technology' elements. Through application of a balanced scorecard, and Anglo's internal assessment of 53 Anglo operations across the globe, potential pilot mine sites were identified with low, moderate and high levels of ICPS maturity, with associated high closure risk or opportunities. Project implementation plans were developed to increase the ICPS maturity at the pilot sites to the required level that will maximise value realisation or minimise value destruction from a mine closure perspective. The paper presents the finding of the evaluation work conducted, will discuss the challenges and process applied in the development of the implementation plans that advance development of Anglo's ICPS.
\end{abstract}

\section{Introduction}

Anglo American Pty Ltd (hereafter referred to as Anglo) is a global and diversified mining business that provides the raw materials essential for economic development and modern life. Anglo has mining operations, growth projects and exploration and marketing activities across southern Africa, South America, Australia, North America, Asia and Europe; these involve a diverse array of commodities, namely coal (thermal and metallurgical), copper, diamonds, iron ore, manganese, nickel, niobium, phosphate and platinum. Anglo employs approximately 150,000 people worldwide.

The concept of planning for mine closure has now existed for a few decades (Lacy 2000; Environment Australia 2002; Australian Government 2006). The overarching philosophy is quite simple "that closure should be considered throughout the lifecycle of a mine, from cradle to cradle" (ICMM 2008). Regardless, there remain very few examples worldwide of successful mine closure and subsequent lease relinquishment, 
with notable exceptions (e.g. Grant 2006; Lacy \& Bennett 2015). A major part of the problem is that closure planning is rarely seen within the culture of the industry as a core business activity, and subsequently it is only occasionally integrated with other mine-planning activities more relevant to the day-to-day operation of the mine (e.g. short/medium mine planning, LOM planning). This is generally due to the lack of ownership of closure issues by the site mine management teams, as closure is either seen as being too far into the future or someone else's problem, despite the establishment of clear closure policy by most mining corporations and the many changes in mine closure related regulation. There are many reasons for this dichotomy, mining corporations are themselves part of this historical and ongoing problem.

The lack of integration of closure planning into mine processes can be exacerbated by the highly variable professional backgrounds of the diverse people asked to integrate mine closure into mine planning (i.e. environmental, engineering, planning, financial, social, legal). However, many opportunities exist to operate sites differently today in this respect, with little impact on operating costs and major decreases in closure liabilities. These opportunities are often not realised for the reasons outlined above and because of the lack of integration of the core elements involved in mine closure (see Figure 1). Grant and Botha (2015) provided three case studies from Anglo operations around the globe where these opportunities had been realising generating value in excess of USD 200M through eliminating risks or prevention of value destruction. Based on the success of these case studies, Anglo commenced the development of an Integrated Closure Planning System (ICPS) in 2014. A primary aim of the concept was to provide a consistent approach over the lifecycle of projects for the reporting and management of long-term liabilities, and just as critically to ensure that operations leave a positive and sustainable legacy for the mine's host communities after the operations have closed.

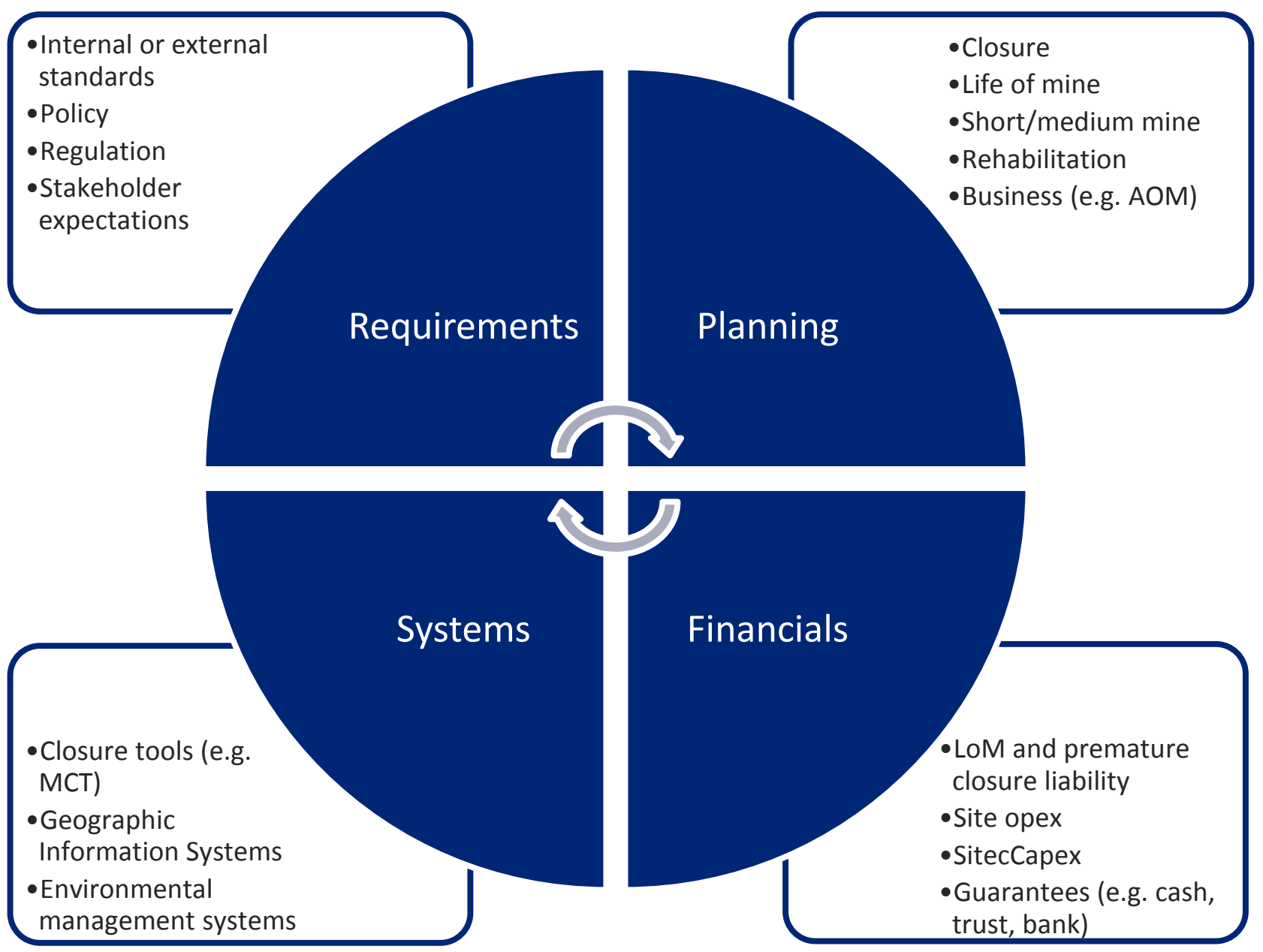

Figure 1 Elements considered to be core to integrated mine closure 
A multi-disciplinary team comprising mine closure, mining engineering/planning, technology and business process experts from Anglo and MWH Consultants was formed to develop the ICPS (MWH 2015).

Importantly, the approach taken by Anglo and MWH was multi-faceted relating to people, process and technology. Historic approaches have often been too narrow in focus and this has led to many false starts. Many industries commonly look to technology as a solution, but these are often not supported by the people involved in the process. Some operators do not clearly understand the problem before they institute a solution, most often because they have not mapped business processes in detail and understood the support the process will need with 'appropriate people' and 'appropriate technology'.

Any business solution is a combination of three key components, which are critical to successful business outcomes; the components are 'People, Process and Technology'. The ICPS approach we describe recognises and aligns those three key areas to develop a successful ICPS solution. Systems are known to achieve $40-60 \%$ effectiveness with process and technology operating to maximum capacity; however, the most effective systems only reach, and retain, a high level of performance with the integration and engagement of people (MWH 2015).

The objective of this paper is to outline the process undertaken to develop an industry leading ICPS and the learnings that have been captured during this journey. This is achieved by firstly outlining the target condition (including technology solutions), current condition and maturity assessment identified and developed in the ICPS project. The assessment of more than 50 of Anglo's operations around the globe is then provided, leading to the identification of three pilot sites of variable ICPS maturity. An example of a detailed implementation plan is then outlined for the pilot sites and conclusions from the project journey thus far are provided.

\section{Anglo ICPS target condition}

This first step originally involved MWH developing an independent target condition for ICPS which was then framed into the Anglo context.

\subsection{Definition of ICPS}

The first step in identifying the target condition is to define what ICPS are and the benefits of achieving high levels of maturity. The agreed definition was subsequently updated to:

"Anglo American's Integrated Closure Planning System (ICPS) combines the various mine planning regimes, internal and external requirements, financial considerations and systems from a people, process and technology perspective, over the lifecycle of operations, to ensure Anglo optimises use of its resources and leaves a positive and sustainable legacy for their host communities post-closure."

Integrating closure planning with the life-of-mine (LOM) planning process will lead to the following benefits:

- More sustainable closure plans.

- Progressive land rehabilitation.

- Reduced risk and liability.

- Positive stakeholder engagement and communication.

- Opportunity for improved lease relinquishment.

- Economic control and financial provision.

- Corporate reputation enhanced.

- Improve shareholder value. 


\subsection{ICPS process design}

A review of existing business processes in Anglo indicated that the ICPS should focus on the level C (Core Processes) and $D$ (Business Process Flows) process layer from a business process hierarchy model perspective (Figure 2). In this hierarchy, level A are business activities, level B are process groupings, level $E$ are operational process flows and level $\mathrm{F}$ are detailed process flows. In relation to Core Processes, seven were identified in the Anglo target condition ICPS (Figure 3), with major inputs and outputs from each process recorded. Importantly, process seven involves review and operates across all of the other six processes.

\section{Process Components}
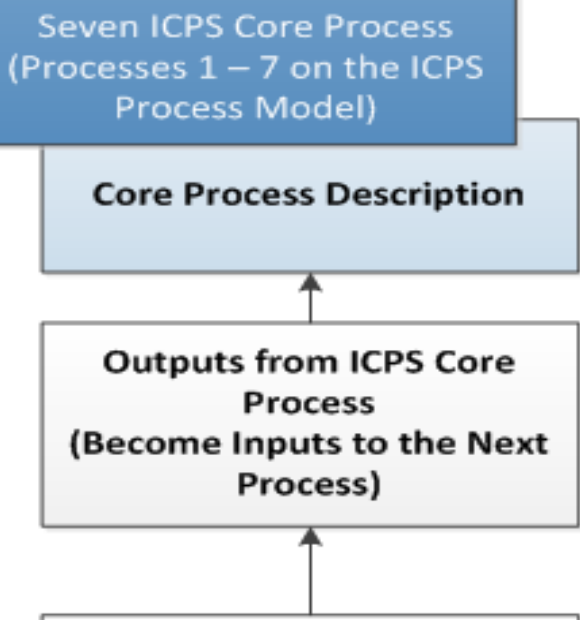

Inputs to Core Process from ICPS Sub Process

Tools, Technology Techniques Utilised Across the Sub Process
Process Levels

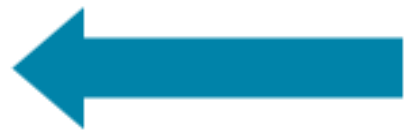

Process Level C

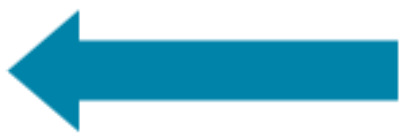

Process Level D

Figure 2

Target condition planned process hierarchy

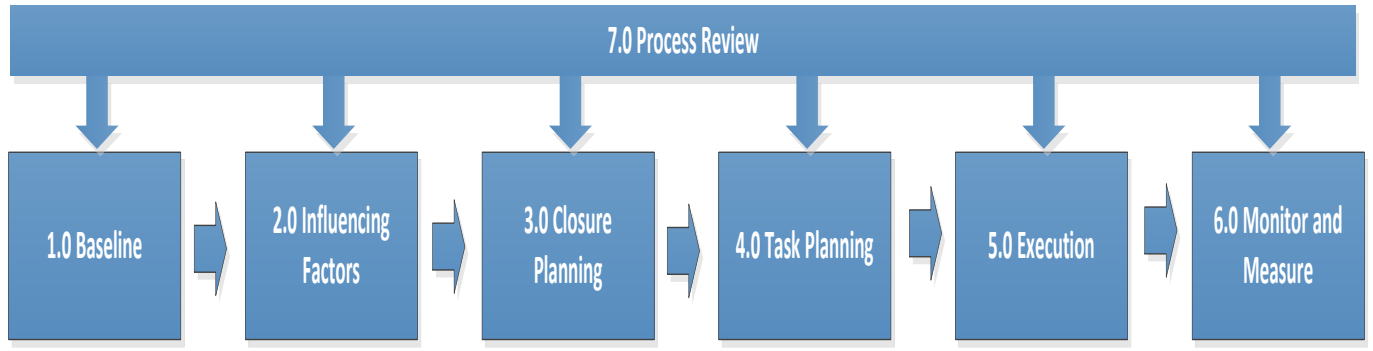

7.0 Process Outputs

- Scorecard Assessment Reports

- ICPSScorecard

- ICPS Improvement Plans

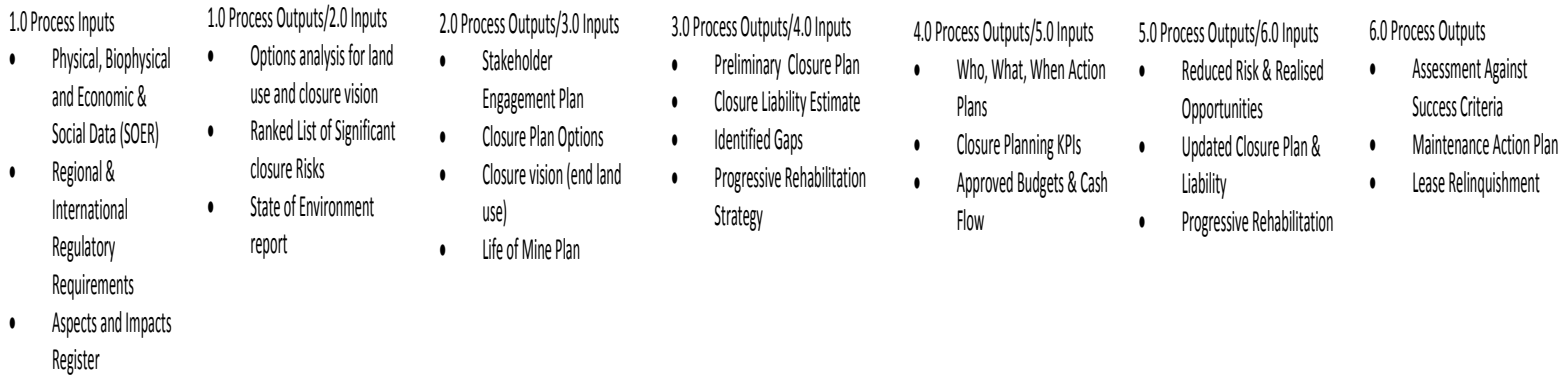

Figure 3 Seven identified ICPS target condition processes 


\subsection{ICPS sub-process design}

A total of 39 sub-processes were identified under the seven processes in the target condition ICPS (Figure 4). During the development of the target condition sub-processes, the significant overlap with the existing Anglo Mine Closure Toolbox (MCT) (Botha 2013) was noted and mapped (see Section 3). For each process and associated sub-processes, all inputs and outputs were mapped along with a RACl chart (Figure 5).

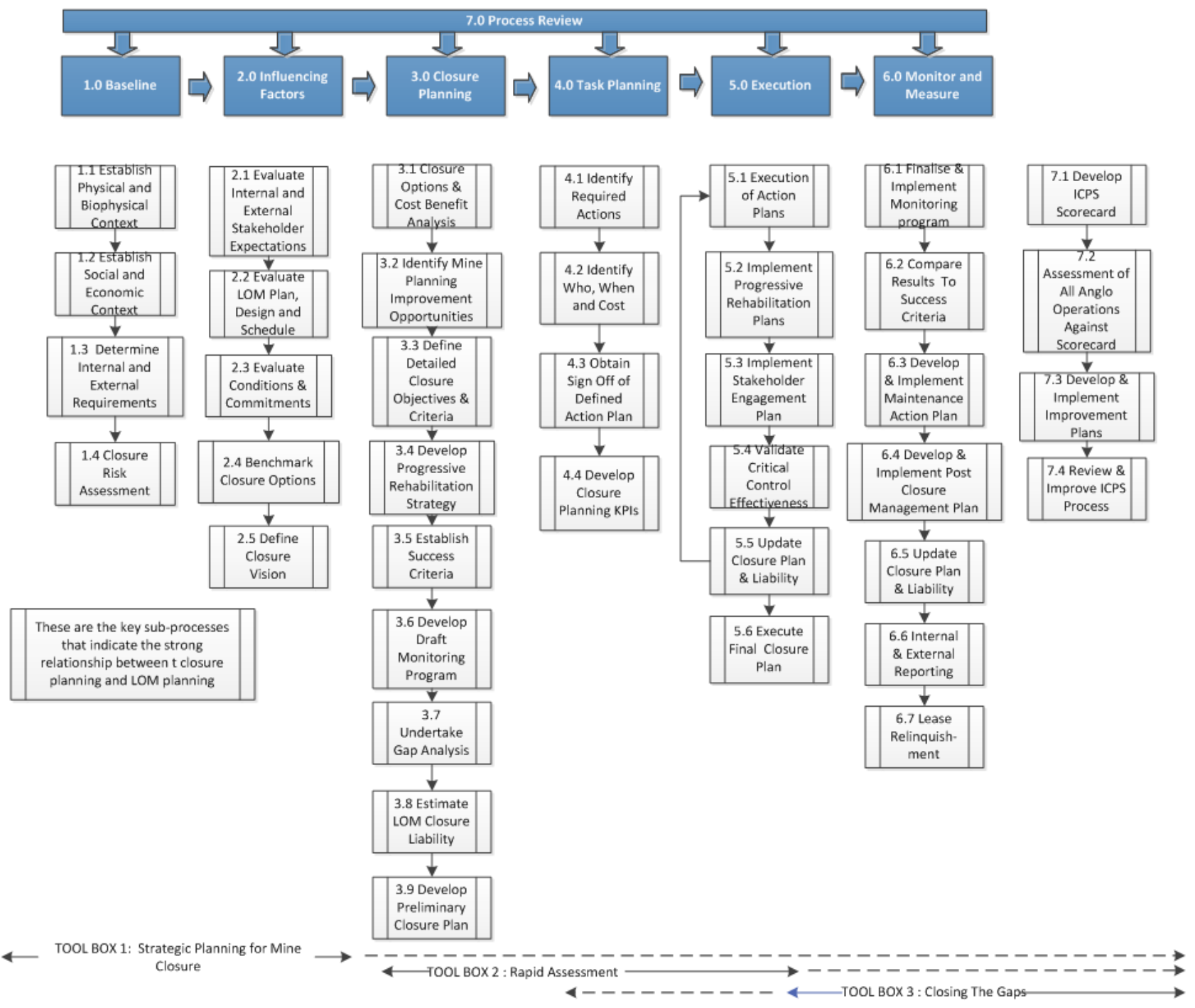

Figure 4 Thirty-nine identified ICPS target condition sub-processes 


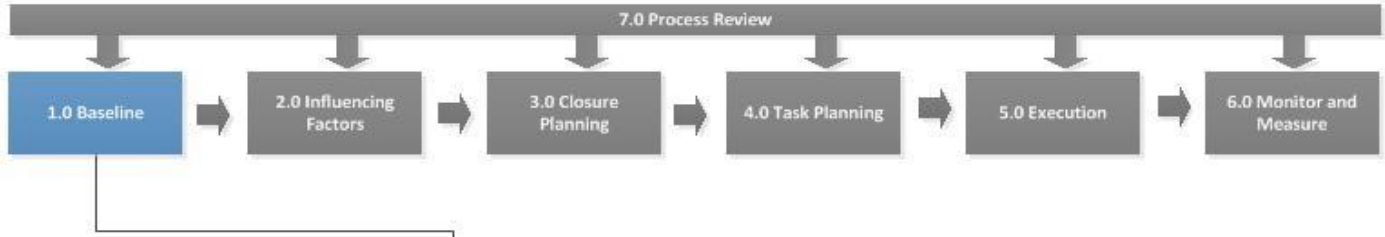

Process Inputs (Bold most important)

- Physical, Biophysical and Economic \& Social Data (SOER)

- Regional \& International Regulatory Requirements

- Individual Project Conditions

- Site History

- Life of Mine Plan (Stage dependent)

- Aspects and Impacts Register

- Internal Standards

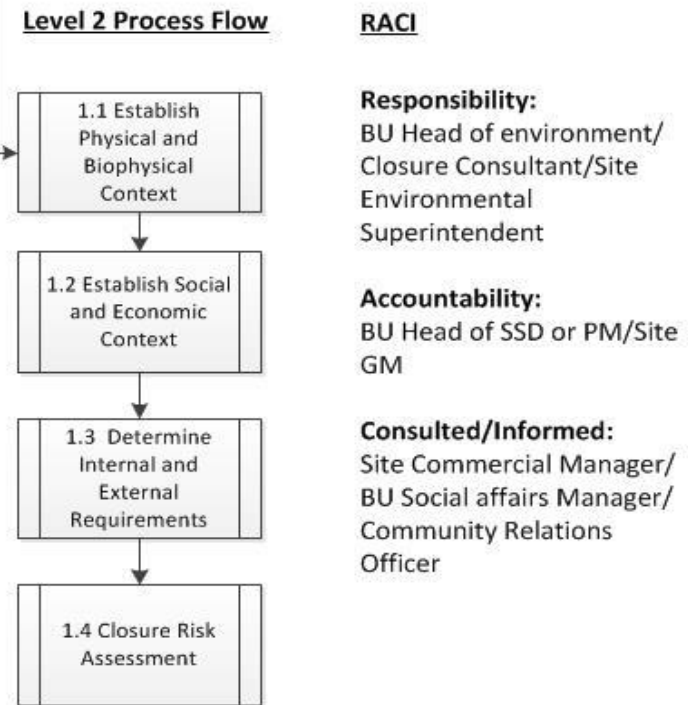

Process Outputs

- Options analysis for land use and closure vision

- Stakeholder \& Community expectations

- Ranked List of Significant closure Risks

- State of Environment report

- Conditions \& Commitments Register

Figure 5 Example of mapping of all inputs, outputs and RACI for ICPS target condition process 1

\subsection{Technology review}

The review undertaken by MWH technology experts focussed on mine planning software, mine closure management software and an integrated platform for the ICPS. These are discussed below.

There are many mine planning software solutions existing on the market today and compatibility has significantly improved over the last five years. Examination of mine planning software currently being used by Anglo identified that more than 30 software solutions applied. The use of mine planning software has now been mapped across Anglo's Business Units (BU) and operations, and a project is underway to consolidate the number of applications to focus on those with the greatest functionality. The conclusion from the MWH experts was that a range of software solutions could be used in the target condition ICPS and that what is currently being used needs to be assessed against business needs at a BU level while being cognisant of people's preference to use what they are familiar with.

Four existing mine closure management software solutions were identified, namely PRAC ${ }^{\mathrm{TM}}(\mathrm{MWH})$, i-Close (i-Globe), Borealis and Infoscope. It was concluded that PRAC ${ }^{\mathrm{TM}}$ had the majority of functionality already in place to meet the target condition while $\mathrm{i}$-Close had the potential to be upgraded to meet functionality requirements. The other software was not evaluated further as they were deemed to have other core purposes not aligned to this project. I-Close is currently being used at one Anglo operation, while PRAC ${ }^{\mathrm{TM}}$ is used at a number of operations in Australia.

No existing platforms that could host and integrate all of the software components required in the target condition ICPS could be identified.

\section{Anglo ICPS current condition}

The MWH team undertook a comprehensive review of current Anglo systems, processes and capability in relation to mine closure planning. This involved reviewing the tools, processes and supporting technology 
related to mine closure that Anglo American currently have in use across their organisation, and identifying weaknesses and gaps in the current processes that are required as part of the proposed target condition. The current state assessment was undertaken via interviews and workshops.

\subsection{Interviews}

The purpose of the focussed interviews was to gain an understanding of:

- The current technology systems employed across the variety of mine sites globally.

- The mine closure planning processes deployed across the organisation.

- The issues that are being faced across the organisation with respect to mine closure.

- The key suppliers and customers to the mine closure process.

All interviewed personnel selected LOM planning as the highest priority issue in relation to ICPS. This was followed by the clear identification of a closure vision, and clear identification of roles and responsibilities (Figure 6). These results were then incorporated into the summary of areas requiring improvement (see Section 3.4).

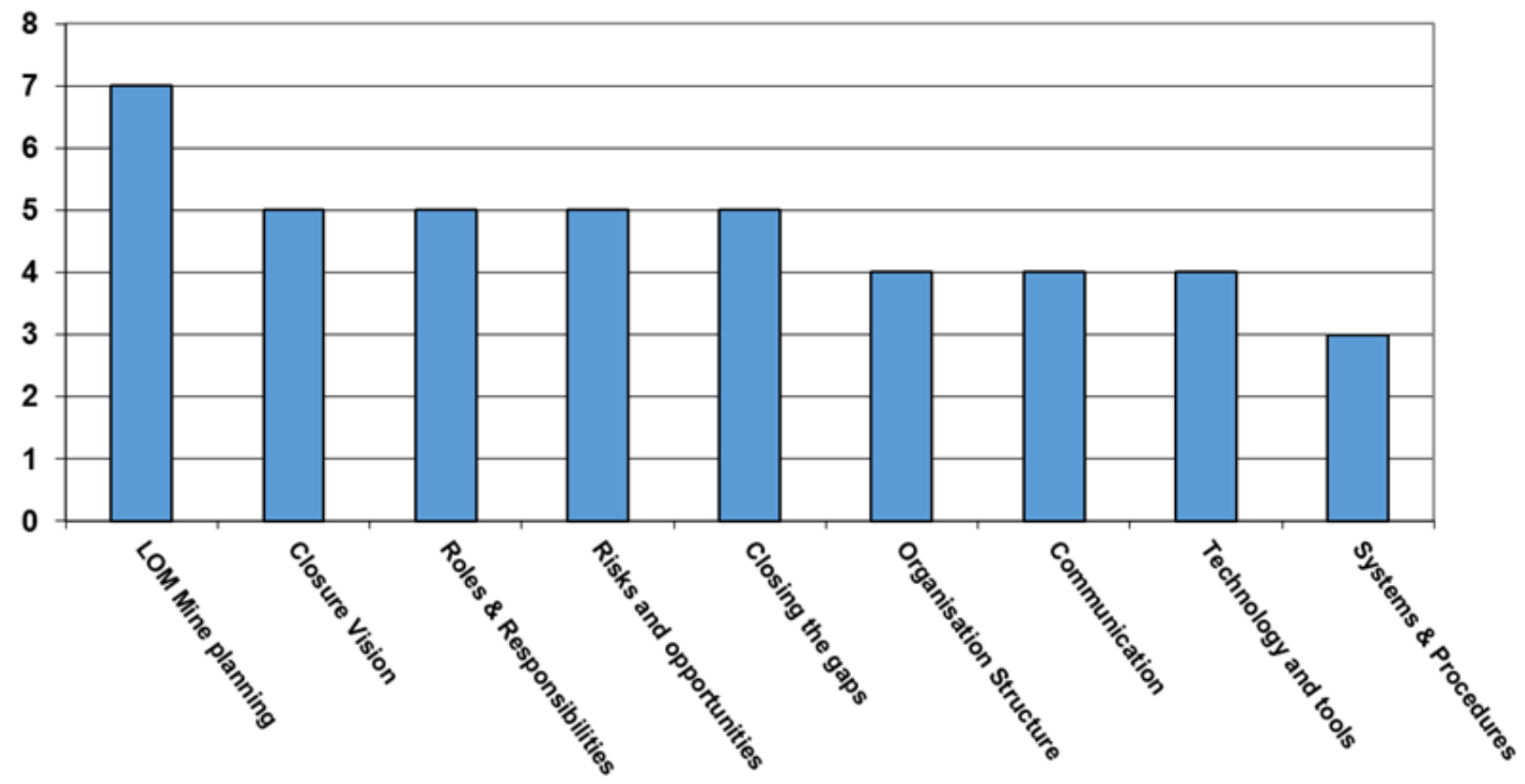

Figure 6 Key issues with ICPS in Anglo current condition

\subsection{ICPS process structure}

Interviews with key staff within Anglo identified considerable numbers of existing processes within the organisation that would be considered part of ICPS. These processes had been defined within CaseWise ${ }^{\mathrm{TM}}$ (a software management system), and were currently being rolled out across the organisation with various levels of uptake. The identified process level within this structure was focussed on the mining lifecycle rather than the ICPS. However, at the operational process flow level across BU's significant work had been completed in relation to mapping of short-, medium- and long-term mine planning.

\subsection{Mine closure toolbox}

Anglo developed the MCT in 2007 with an updated version released in 2013. The MCT is available in three languages (English, Portuguese and Spanish) on the internet as freeware for general use. The MCT has three tools, namely: strategic planning, rapid assessment and closing the gaps (Figure7). The vast majority of Anglo 
operations have closure plans at least moderately aligned with the $\mathrm{MCT}$, given it has been eight years since the original release of the toolbox. This puts Anglo in a unique and well advanced position to develop a full ICPS having a common well-structured approach to mine closure planning already in place. Mapping of the target condition (Section 2) identified significant overlap in many areas between the MCT approach and the ICPS (Figure 4). Importantly, the ICPS process mapping takes the MCT framework outside of just the closure planning realm and integrates it into the operational phase of a site.

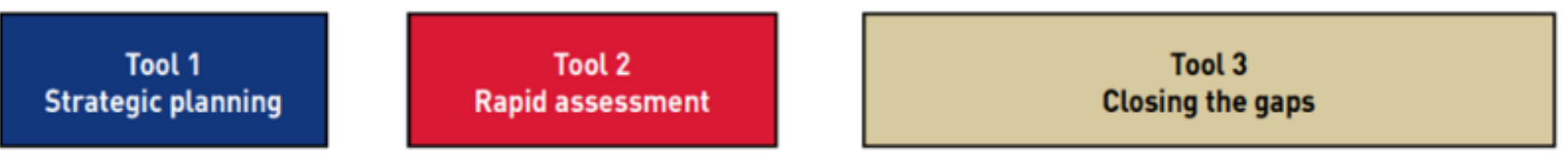

Post-closure vision defined from the outset

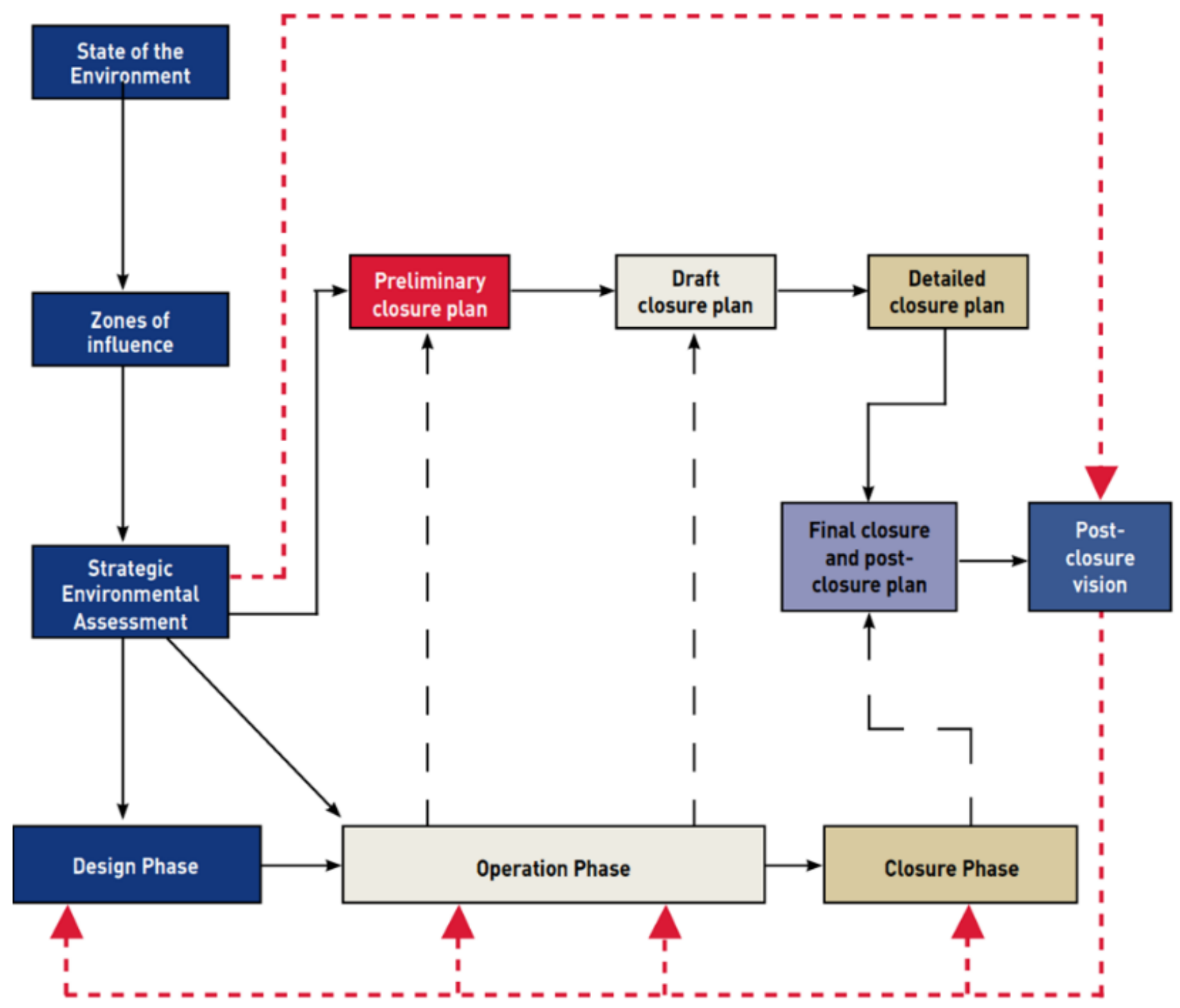

Post-closure vision influences design, operation and closure

Figure 7 Mine closure toolbox structure (after Botha 2013)

\subsection{Summary of improvement areas}

Based on the assessment of the current condition, seven major areas requiring improvement were identified across the people, process and technology components of ICPS (Table 1). This will be used to assist in the development of detailed improvement plans for the selected pilot sites (see Section 5). 
Table 1 Summary of major ICPS improvement areas

\begin{tabular}{|c|c|c|c|}
\hline \multirow{2}{*}{$\begin{array}{l}\text { Details of } \\
\text { observed issue }\end{array}$} & \multicolumn{3}{|c|}{ Improvement areas } \\
\hline & Process & People & Technology \\
\hline LOM planning & Limited integration & $\begin{array}{l}\text { Understanding and } \\
\text { limited engagement }\end{array}$ & $\begin{array}{l}\text { Information links/no } \\
\text { platform }\end{array}$ \\
\hline Gaps not closed & Completion of actions & Roles and responsibilities & Limited system \\
\hline Closure vision & $\begin{array}{l}\text { LOM process/stakeholder } \\
\text { input }\end{array}$ & $\begin{array}{l}\text { Linked to post-closure } \\
\text { land use }\end{array}$ & Stakeholder/media \\
\hline Opportunity & $\begin{array}{l}\text { Lack of capture - no } \\
\text { formal process }\end{array}$ & $\begin{array}{l}\text { Limited awareness of } \\
\text { potential value }\end{array}$ & Enabling system missing \\
\hline $\begin{array}{l}\text { Option } \\
\text { visualisation }\end{array}$ & $\begin{array}{l}\text { Inconsistent - limited } \\
\text { guidance on requirement }\end{array}$ & $\mathrm{RACl}$ & Choice and ease of use \\
\hline $\begin{array}{l}\text { Roles and } \\
\text { responsibilities }\end{array}$ & $\begin{array}{l}\text { RACl for closure planning } \\
- \text { all levels }\end{array}$ & KPI's to closure process & $\begin{array}{l}\text { Enabling and supporting } \\
\text { system }\end{array}$ \\
\hline Risk & Quality - control & $\begin{array}{l}\text { Limited knowledge/lack } \\
\text { of ownership }\end{array}$ & Platform available to host \\
\hline
\end{tabular}

\section{$4 \quad$ ICPS maturity scorecard and assessment}

\subsection{Development of the maturity scorecard}

A maturity assessment scorecard was developed involving 33 of the 39 identified sub-processes in the target condition ICPS. The seventh process involving review was not included as this is not directly relevant to assessing existing operations maturity. For each sub-process, a definition of the condition relating to five levels of maturity were provided, namely:

- Level 0 Innocence: Absence of capabilities. Not aware that a closure planning process exists. There is no plan or investigation into improving the current practices.

- Level 1 Awareness: Individuals have become aware that the current closure planning practices are inadequate and that changes are required, to improve the process.

- Level 2 Understanding: The function is developing an improvement plan for the closure planning process and the improvements are being implemented in varying degrees.

- Level 3 Competence: The closure planning function has implemented quality management processes throughout and the practice is now an accepted way of doing business with established core closure planning processes and services in place throughout the organisation.

- Level 4 Excellence: The organisation is continually reviewing the integrated closure planning processes, and implementing improvements. The organisation is recognised as having a leading edge in this ICPS, industry-wide.

Anglo are targeting level three maturity for all sub-processes, with level four pursued where there is a compelling business case. An example of the maturity conditions for the Baseline process is provided in Figure 8. 


\begin{tabular}{|c|c|c|c|c|c|c|c|c|}
\hline $\begin{array}{c}\text { Process } \\
\text { Step } \\
\end{array}$ & $\begin{array}{l}\text { Step } \\
\text { No. }\end{array}$ & $\begin{array}{l}\text { Question } \\
\text { No. }\end{array}$ & Question & $\begin{array}{c}\text { Maturity level } 0 \\
\text { INNOCENCE }\end{array}$ & $\begin{array}{c}\text { Maturity level } 1 \\
\text { AWARENESS }\end{array}$ & $\begin{array}{c}\text { Maturity level } 2 \\
\text { UNDERSTANDING }\end{array}$ & $\begin{array}{c}\text { Maturity level } 3 \\
\text { COMPETENCE }\end{array}$ & $\begin{array}{c}\text { Maturity level } 4 \\
\text { EXCELLENCE }\end{array}$ \\
\hline \multirow[t]{4}{*}{ BASELINE } & \multirow{4}{*}{1} & $\begin{array}{l}1.1 \\
\text { Establish } \\
\text { Physical } \\
\text { and Bio- } \\
\text { Physical } \\
\text { Context }\end{array}$ & $\begin{array}{l}\text { Has the } \\
\text { physical and } \\
\text { biophysical } \\
\text { context been } \\
\text { established } \\
\text { for the } \\
\text { project? }\end{array}$ & $\begin{array}{l}\text { The site has taken } \\
\text { no action to } \\
\text { establish the base } \\
\text { line physical and } \\
\text { biophysical data }\end{array}$ & $\begin{array}{l}\text { The site } \\
\text { understands the } \\
\text { need for baseline } \\
\text { physical and } \\
\text { biophysical context } \\
\text { and have collected } \\
\text { data for a few of } \\
\text { the requirements }\end{array}$ & $\begin{array}{l}\text { The site has an } \\
\text { established and } \\
\text { documented a } \\
\text { baseline physical } \\
\text { and biophysical } \\
\text { data set. }\end{array}$ & $\begin{array}{l}\text { The site has an } \\
\text { established base } \\
\text { line physical and } \\
\text { biophysical data } \\
\text { set and is updated } \\
\text { as a part of the } \\
\text { sites closure } \\
\text { planning process }\end{array}$ & $\begin{array}{l}\text { The site has a well } \\
\text { established } \\
\text { baseline physical } \\
\text { and biophysical } \\
\text { data set integrated } \\
\text { into the site EMS } \\
\text { and integrated } \\
\text { closure planning } \\
\text { processes, } \\
\text { assigned RACl and } \\
\text { updated in line } \\
\text { with the mine } \\
\text { (long, medium, and } \\
\text { short term) } \\
\text { planning standards }\end{array}$ \\
\hline & & $\begin{array}{l}1.2 \\
\text { Establish } \\
\text { Social And } \\
\text { Economic } \\
\text { Context }\end{array}$ & $\begin{array}{l}\text { Has the social } \\
\text { and } \\
\text { economic } \\
\text { context been } \\
\text { established } \\
\text { for the } \\
\text { project? }\end{array}$ & $\begin{array}{l}\text { The site hasn't } \\
\text { established the } \\
\text { social and } \\
\text { economic context } \\
\text { for the site. }\end{array}$ & $\begin{array}{l}\text { The site has } \\
\text { established some } \\
\text { of the social and } \\
\text { economic context } \\
\text { but is not updated } \\
\text { regularly }\end{array}$ & $\begin{array}{l}\text { The site has a well } \\
\text { established social } \\
\text { and economic } \\
\text { context and } \\
\text { reviewed and } \\
\text { updated annually }\end{array}$ & $\begin{array}{l}\text { The site } \\
\text { understands well } \\
\text { the social and } \\
\text { economic context, } \\
\text { is reviewed and } \\
\text { updated annually } \\
\text { and is subject to a } \\
\text { review and } \\
\text { assessment } \\
\text { process }\end{array}$ & $\begin{array}{l}\text { The site has a well } \\
\text { established social } \\
\text { and economic } \\
\text { context, that is } \\
\text { reviewed and } \\
\text { updated annually, } \\
\text { is subject to an } \\
\text { assessment } \\
\text { process that } \\
\text { includes actions to } \\
\text { close out any gaps } \\
\text { and is well } \\
\text { established within } \\
\text { the closure } \\
\text { planning process. }\end{array}$ \\
\hline & & $\begin{array}{l}1.3 \\
\text { Determin } \\
\text { e Internal } \\
\text { and } \\
\text { External } \\
\text { Requirem } \\
\text { ents }\end{array}$ & \begin{tabular}{|l|} 
Have the \\
internal and \\
external \\
requirements \\
been \\
determined?
\end{tabular} & $\begin{array}{l}\text { No internal or } \\
\text { external } \\
\text { requirements have } \\
\text { been determined }\end{array}$ & $\begin{array}{l}\text { Internal standards } \\
\text { and guidelines } \\
\text { have only been } \\
\text { determined }\end{array}$ & $\begin{array}{l}\text { All internal policies, } \\
\text { standards and } \\
\text { guidelines and all } \\
\text { regulator } \\
\text { conditions and } \\
\text { commitments have } \\
\text { been determined }\end{array}$ & $\begin{array}{l}\text { All internal policies, } \\
\text { standards and } \\
\text { guidelines, all } \\
\text { regulatory } \\
\text { conditions and } \\
\text { commitments and } \\
\text { all industry } \\
\text { signatory } \\
\text { standards have } \\
\text { been determined } \\
\text { and included in a } \\
\text { conditions and } \\
\text { commitments } \\
\text { register }\end{array}$ & $\begin{array}{l}\text { All internal policies, } \\
\text { standards and } \\
\text { guidelines, all } \\
\text { regulatory } \\
\text { commitments and } \\
\text { all industry } \\
\text { signatory } \\
\text { standards have } \\
\text { been determined, } \\
\text { are reviewed and } \\
\text { assessed annually } \\
\text { and well } \\
\text { established within } \\
\text { the sites conditions } \\
\text { registers. }\end{array}$ \\
\hline & & $\begin{array}{l}1.4 \\
\text { Closure } \\
\text { Risk } \\
\text { Assessme } \\
\text { nt }\end{array}$ & $\begin{array}{l}\text { Has a closure } \\
\text { risk } \\
\text { assessment } \\
\text { been } \\
\text { undertaken? }\end{array}$ & $\begin{array}{l}\text { No risk assessment } \\
\text { for mine closure is } \\
\text { undertaken and } \\
\text { site risk and } \\
\text { opportunity } \\
\text { registers contain } \\
\text { no closure issues }\end{array}$ & $\begin{array}{l}\text { A closure risk } \\
\text { assessment has } \\
\text { been undertaken } \\
\text { but no closure risk } \\
\text { register is in place } \\
\text { or included in the } \\
\text { closure plan }\end{array}$ & $\begin{array}{l}\text { Closure risk and } \\
\text { opportunity } \\
\text { assessments } \\
\text { undertaken as } \\
\text { apart of the closure } \\
\text { planning process } \\
\text { and closure risks } \\
\text { are included in } \\
\text { overall site risk } \\
\text { register but no } \\
\text { follow-up on risk } \\
\text { controls and } \\
\text { actions are taken }\end{array}$ & $\begin{array}{l}\text { Closure risk and } \\
\text { opportunities well } \\
\text { documented within } \\
\text { the closure } \\
\text { planning process, } \\
\text { closure risk } \\
\text { registers well } \\
\text { maintained, } \\
\text { controls assessed } \\
\text { at each closure } \\
\text { planning cycle, } \\
\text { risks and } \\
\text { opportunity } \\
\text { controls assessed } \\
\text { annually }\end{array}$ & $\begin{array}{l}\text { Closure risk and } \\
\text { opportunities } \\
\text { process well } \\
\text { established within } \\
\text { the closure } \\
\text { planning process, } \\
\text { closure risk } \\
\text { registers well } \\
\text { maintained, risk } \\
\text { controls and } \\
\text { opportunity action } \\
\text { plans assessed, } \\
\text { and actions } \\
\text { reflected within } \\
\text { closure plan } \\
\text { options. }\end{array}$ \\
\hline
\end{tabular}

Figure 8 Example of maturity assessment condition descriptions for process 1 


\subsection{Assessment of existing operations ICPS maturity}

A total of 53 Anglo operations across all BU's around the globe were assessed against the ICPS maturity conditions. The assessment was undertaken by members of the Anglo closure planning team, but data was checked with the BU staff involved in ICPS. Outputs are able to be viewed as individual operation radar charts (Figure 9), all operations within a BU according to process and all operations with stacked scores across the six processes and ranked (Figure 10). The results show a range of total scores from 4 to 16 indicating significant variability. Some BU's exhibited low maturity across all sites indicative of centralised management of mine closure, while others demonstrated significant variability between operations indicative of operational level management of mine closure. The baseline and influencing factors processes were rated highly across nearly all operations due to the requirement of the MCT to undertake strategic planning. Significant variability was observed in the task planning and execution processes, with proactive operations scoring highly. The monitoring and measuring process is somewhat influenced by the stage that an operation is at in relation to the mine lifecycle, with those in the closure phase scoring highest.

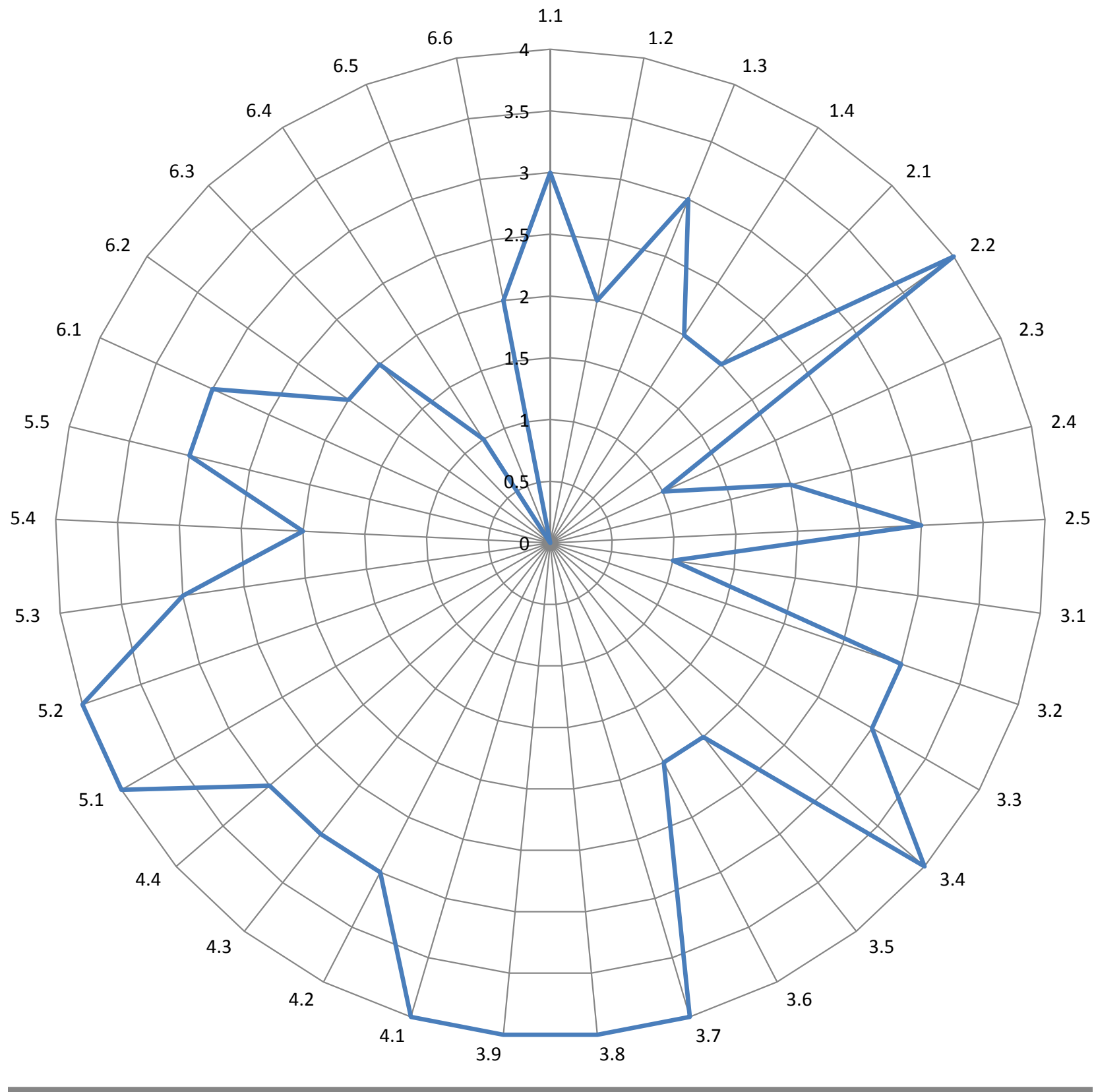

Figure 9 Example of radar chart for a relatively mature operation. Numbers on the chart refer to sub-processes contained in Figure 4 


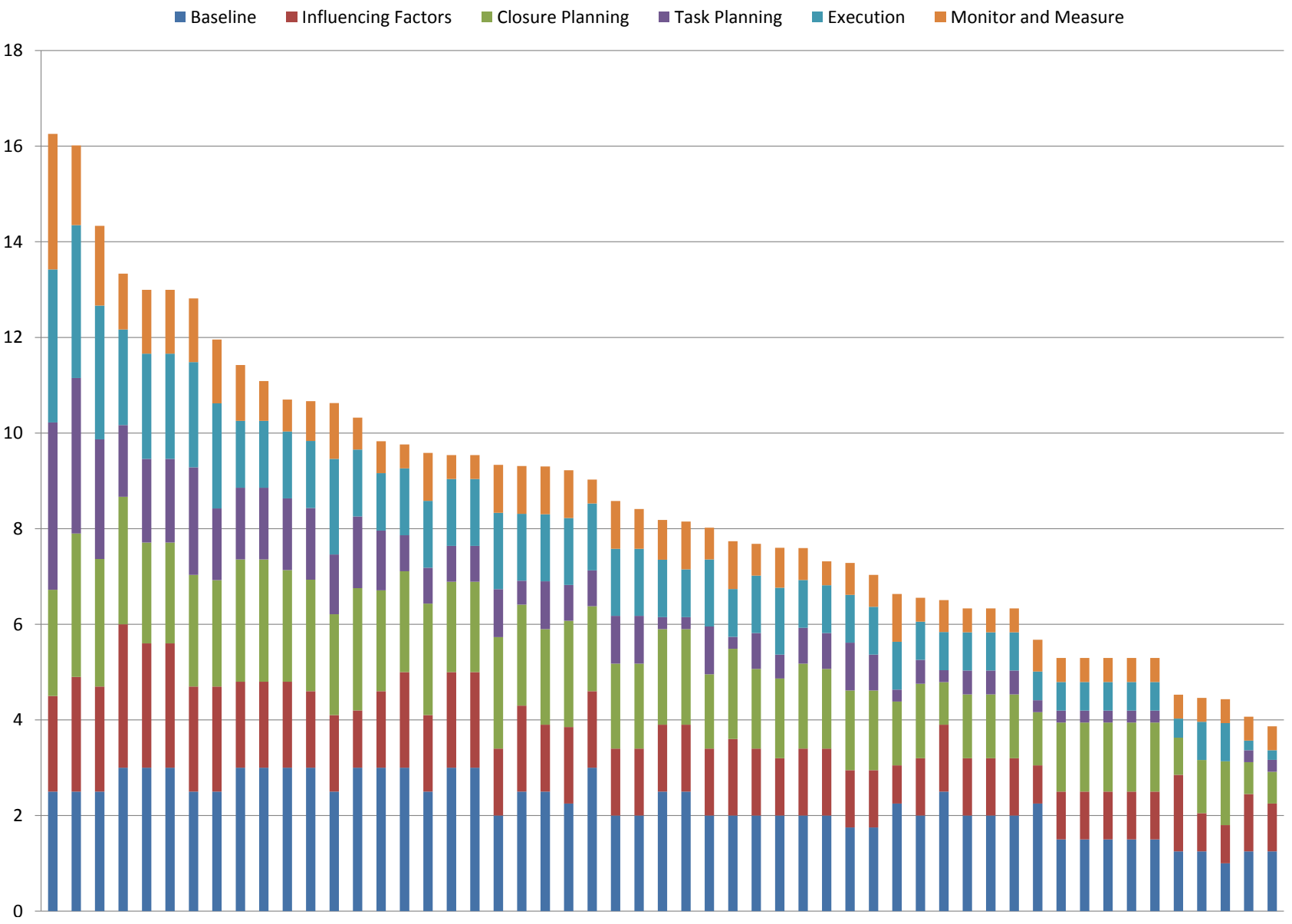

Figure 10 Stacked bar chart for the six processes across the 53 Anglo operations

\section{$5 \quad$ Selection of pilot sites and development of implementation plans}

\subsection{Selection of pilot sites}

To assist in the selection of pilot sites to trial the implementation of the target condition ICPS, results from a recent prioritisation study focussed on closure risk and opportunity was superimposed on the ICPS range standardised maturity scores (Figure 11). This allowed sites to be short-listed that had the greatest closure risk and opportunities associated with them, thereby maximising the value likely to be generated from the pilot studies. It was decided that one site of each category (low, moderate or high ICPS maturity), making a total of three sites, was selected to maximise the diversity of likely solutions and associated implementation plans. 


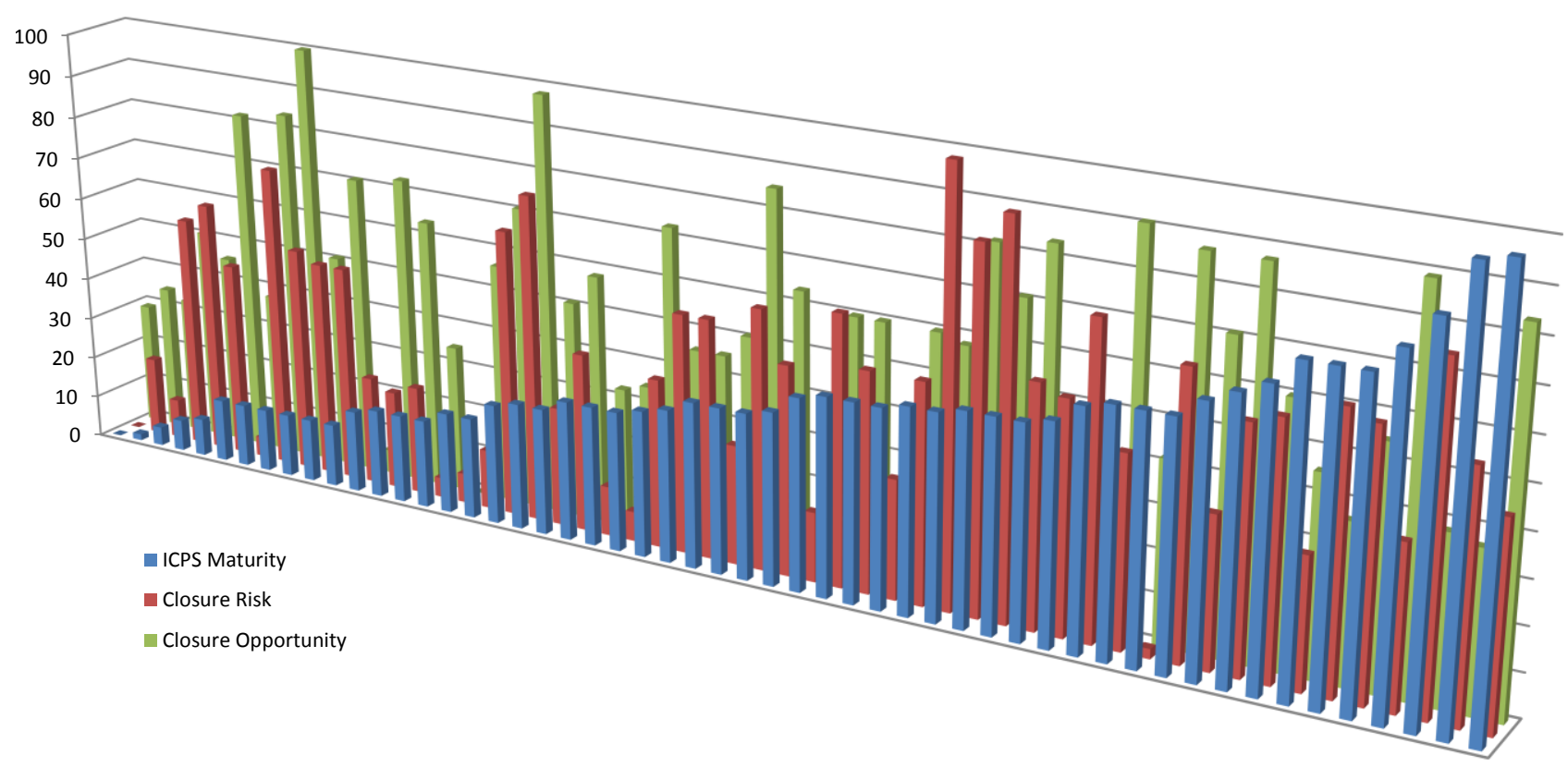

Figure 11 ICPS maturity, closure risk and closure opportunity across 53 Anglo operations

\subsection{Development of implementation plans}

Once the three pilot sites were chosen, a first pass implementation plan was developed to bring sites up to a minimum maturity level of three across all 33 assessed ICPS sub-processes. Examples of identified actions within the implementation plan included:

- Update the existing closure plan including the risk assessment and re-doing the gap analysis.

- Organise a workshop with LOM planners and environmental professionals to investigate opportunities for integrated planning that will add value.

- Develop a methodology for assessing the value proposition for opportunities related to integrated closure planning (e.g. cost benefit analysis).

- Develop a rehabilitation strategy for the site including success criteria and an associated monitoring program.

- Draft success criteria and an associated monitoring program.

- Undertake a local, regional, national and international benchmarking exercise.

- Develop a stakeholder engagement plan related to closure.

- Investigate options to implement an improved system for the calculation of closure liability with a Geographical Information System (GIS) link.

- Introduce process for tracking of actions developed from the gap analysis in the MCT process.

- Develop an obligations register related to all closure permit requirements.

- Get closure planning KPI's into site leadership team member's performance contracts.

A number of challenges were experienced in developing the implementation plans and securing the three pilot sites. Primarily, significant decline in commodity prices in 2014/5 made it extremely difficult to make a compelling case for immediate change, almost regardless of how strong the business case was. Another challenge for the team was managing cultural and language differences across the pilot sites located in South Africa, Botswana, Brazil and Australia. However, the current instability being experienced by mining around the globe highlights the importance of making a compelling case for integration of mine closure planning into the business and makes this initiative more compelling than ever. 


\section{Conclusion}

The whole concept of planning for closure is not new. In 2006, the International Council of Mining and Metals (ICMM) summarised the thinking at that time as:

"Integrated closure planning is a dynamic process which must commence in tandem with the other planning aspects of a mining process and must contain social and environmental aspects at the same core level of planning importance as waste management and revegetation, the more traditional rehabilitation components of closure plans. It will be this approach to sustainability planning that will give the greatest chance of longevity to an industry designed to exploit a non-renewable resource - proof that there can be long-term benefits to the people whose environments are affected by mining operations." (ICMM 2006)

However, ICMM also recognised that integration is neither complete nor formalised for a large majority of companies. In this paper, Anglo American is showing its proposed pathway to formalisation of an ICPS. This requires integration of planning activities, internal and external requirements, financials and system integration from a people, process and technology perspective. The first step to achieving this has been the identification of the target ICPS involving seven processes and 39 sub-processes. The assessment of 53 of Anglo's operations across the globe indicated significant variability in maturity in relation to ICPS. The next phase of the project will involve the implementation of improvement plans at three pilot sites of variable maturity (low, medium and high) to attain a minimum maturity level of competence across all sub-processes in the ICPS. This will be followed by a further review of the ICPS incorporating findings from the pilot sites and a potential global rollout across Anglo's operations.

\section{Acknowledgement}

Andrew Hurford, Michael Slight, Derek Vogelsang, Rudolph Botha, Erich Heymann, Dave Drinkwater, Michael Livingston-Blevins and Richard Gawthorpe are all acknowledged for their significant contributions to this project.

\section{References}

Australian Government 2006, 'Mine Closure and Completion', Leading Practice Sustainable Development Program for the Mining Industry, Department of Industry Tourism and Resources, Commonwealth of Australia, Canberra.

Botha, PR 2013, Anglo American mine closure toolbox, version 2, Anglo Operations Pty Ltd, London.

Environment Australia 2002, 'Mine decommissioning', Best practice environmental management in mining series, Environment Australia, Canberra.

Grant, CD 2006, 'Decommissioning Alcoa's first bauxite mine in the Jarrah Forest of Western Australia: Cradle to grave', in A Fourie \& M Tibbett (eds), Proceedings First International Seminar on Mine Closure, Australian Centre for Geomechanics, Perth, pp. 287-297.

Grant, CD \& Botha PR 2015, 'Integrated closure planning: case studies on changing operational strategies to reduce closure liabilities', in A Fourie, M Tibbett, L Sawatsky \& D van Zyl (eds), Proceedings of the Tenth International Seminar on Mine Closure, Keynotes and Plenaries, InfoMine.

ICMM (International Council on Mining and Metals) 2006, Integrated mine closure, ICMM, London.

ICMM (International Council on Mining and Metals) 2008, Planning for integrated mine closure: toolkit, ICMM, London.

Lacy, H 2000, 'Planning the Process of Closure "Close As You Go"', in Proceedings Planning for Mine Closure - An Operator's Guide, Australian Centre for Geomechanics Seminar No. 2009, Perth.

Lacy, HWB \& Bennett, KE 2015, Updating Australia's leading practice sustainable development (LPSD) mine closure handbook for 2015: Closing the gaps and understanding the mineral resource legacy, in A Fourie, M Tibbett, L Sawatsky \& D van Zyl (eds), Proceedings of the Tenth International Seminar on Mine Closure, Keynotes and Plenaries, InfoMine.

MWH 2015, Integrating Systems to Optimise Mine Closure Planning: Solution Analysis, Internal Document Anglo American May 2015. 